\title{
Effects of Financial Determinants on Dividend Payout: Evidence from Nepalese Retail Banks
}

\author{
Makshindra Thapa, $P h D$ \\ Lecturer, Tribhuvan University \\ Visiting Faculty, Nesfield International College \\ Email: tmakshindra@yahoo.com
}

\begin{abstract}
This paper aims to examine the impact of five commonly used dividend determinants as; net profit, cash flow, size, market to book value, and slack on the dividend payout ratio of 19 Nepalese commercial banks. This study uses secondary data collected from annual financial statements of the banks listed on the Nepal Stock Exchange. A total of 95 observations of the variables five fiscal years are considered. The method used casual comparative research design and regression analysis is conducted. The results showed a positive and significant effect of two variables; market to book value and slack on dividend payout ratio. The result also showed the positive effect of size on the dividend payout ratio. However, the results indicated a negative effect of profitability and cash flows on the dividend payout ratio of the banks.
\end{abstract}

Keywords: dividend payout ratio, net profit, size, cash flow, market to book value, investment opportunity

\section{Introduction}

In a company's life, dividend is a very pivotal issue. Since companies mostly rely on share capital issued for the general public and in contrast to debt capital bearing a fixed rate of return, equity capital receives the dividend as a return. The dividend, therefore, is a key factor to attract and maintain investors in the form of shareholders for the firm's capital. Most importantly equity capital is a long-term source of capital hence the dependable too thus dividend policies and decisions are most critical issues in managing firm capital. The dividend policy influences the amount of share of equity capital in a firm's capital structure. Dividend policy is the central issue in corporate finance; it has captivated many researchers' interests. In the views of Allen and Michaely (2003) the dividend policies, as well as the 'dividend puzzle', need more effort and researches to be thoroughly understood. In addition, Brealey and Myers (2005) have stated that dividend decision is one of the top ten unresolved problems in finance.

Since dividend decisions not only affect the short-run performance of a firm but they have significant implications and far-reaching consequences. Managers are more 
concerned to make a balance between the stockholders' expectations and forms perpetual succession. An appropriate dividend decision satisfies both the capital requirements for operation, growth, and stockholder's expectations. There are many theories that provide theoretical bases in formulating dividend decisions among them the transaction cost theory, the agency cost theory, the signaling theory, and the firm life cycle theory are more applied.

The existing literature on dividend decisions suggests plenty of potential determinants. The more prominent determinants include protection against liquidity, after-tax earnings of the firm, liquidity, and cash flow consideration, stockholders' expectation/preference, future earnings, past dividend practices, return on investment, industry norms, legal constraints, growth prospects, inflation, and interest rate (Foong, Zakaria, \& Tan, 2007). Besides these, many of the previous studies have analyzed the effect of market-to-book value and investment opportunity on dividend pay decisions.

In the Nepalese context, the role of the financial sector and more specifically the retail banking sector has immensely grown during the early 90s. The only secondary capital market of the country is dominated by these financial institutions. Both the managers and investors are more concerned about dividend decisions as this one of the most attractive sectors for public investment. This paper intends to assess whether the previous results on dividend determinants and their effect on dividend payout are applicable in the context of commercial banks of Nepal.

\section{Objective of the study}

This paper is focused on examining the impact of financial determinants (viz. net profits, market to book value ratio, total assets, cash flow, and slack) of selected commercial banks of Nepal on dividend payout ratio.

\section{Literature review}

The amount of dividend is the prime motivator for the investors as it influences share price, company capital, and then overall financial health. Company dividend decisions are dependent on many factors. According to pecking order theory, the companies having a high growth rate will generally experience high investment requirements and in turn, will have a lower dividend payout ratio. This is because companies finance the new investment opportunity from their internal finance first and if external finance is required they issue debt finance before equity finance so as to reduce the information asymmetry costs and transaction costs (Myers and Majluf, 1984). So there is an inverse relationship between investment opportunity and dividend payout ratio. 
The transaction cost theory states that the firms having a higher proportion of debt finance in total capital will have a higher level of commitment to pay the fixed interest charges and this will reduce the dividend payment to common equity shareholders (Higgins, 1972 and Fama, 1974). According to agency cost theory, the payment of dividends to common equity shareholder will reduce the excess free cash flow available with the manager thereby reducing the agency problem between the manager and shareholders (Jensen \& Meckling, 1976; Rozeff, 1982; and Easterbrook, 1984).

Furthermore the signaling theory advocates that the firms which increase significantly dividend payment enjoy the increase in share prices whereas those firms omitting or reducing significantly dividend payment face a decline in share prices. Therefore, announcement of increased dividend payments by a company gives strong signals about the bright future prospects of the company. Thus managers use higher dividend pay decisions to satisfy and attract the investors. Consequently, the managers have private information about the firm's current condition and future prospects which is not known to the outsiders. The managers can convey this private information to the shareholders in the form of dividend (Bhattacharya, 1979, John and Williams, 1985, and Miller \& Rock, 1985). Mueller (1972) in the firm life cycle theory argues that any firm has a well-defined life cycle and is fundamental to the firm life cycle theory of dividend. The mature firms have less investment opportunities, more accumulated profit and retained earnings which cause them to pay more dividends.

\section{Effect of determinants and dividend payout linkage}

\section{Net Profits and Dividend Payouts}

Principally profitability is a basic determinant and a firm in profit pays higher dividends. Most of the managers rely on the existing profit level while determining dividends to the stockholders. According to Fama and French (2001), profit represents the capacity of a corporation to pay dividends, and thus it has a positive relationship with dividends. Most of the previous studies (Dąbrowska, 2020; Mushtaq, 2016; Refra \& Widiastuti, 2014; Alala, Christopher, Douglas, Robert, \& Musiega, 2013; Javid \& Ahmed, 2009; Shubiri, 2011; Al-Kuwari, 2009; Al-Malkawi, 2007; Amidu \& Abor, 2006; Aivazian et al., 2003) have suggested for positive and significant effect of net profit on dividend payout ratio. However, some studies have reported a negative influence of profit on dividend payout as Amidu and Abor (2006) study results revealed a negative and significant link of profitability with dividend payout.

\section{H1: Profitability has positive impact on dividend payout.}




\section{Market to Book Value Ratio and Dividend Payouts}

The market-to-book value ratio indicates the value that the market places on the common equity or net assets of a firm (Lee \& Makhija, 2009) and is a reflection of the ability of firm managers to use assets effectively and to grow the firm. As per the signaling theory, the managers may influence investors by signaling the market through its dividend policy. A high rate of dividend payout signals about a better financial position of the firm hence attracts more investors thus market to book value ratio has a positive effect on dividend payout. However previous studies have shown mixed results for this influence. The study of Amid and Abor (2006) found a significant negative relationship between the market to book value ratio and the current dividend payouts. In contrast, some studies have reported a positive relationship with dividends (Omran \& Pointon, 2004; Gill, Biger, \& Tibrewala, 2010; Essa et al., 2012; Echchabi \& Azouzi, 2016).

\section{H2: Market to book value ratio has a positive impact on dividend payout.}

\section{Size and Dividend Payouts}

In the general size of a firm influences dividend decisions as large firms are more likely to be mature and better relationship management. Thus they have easier access to capital markets and should be able to pay more dividends. This relationship is supported by the transaction cost explanation of dividend. The previous literature supports a positive relationship between the firm size and its dividend policy. In this context, Eriotis (2005) argued that size is the significant factor affecting the dividends payouts. Lloyd and William (1985) reported a positive relationship between the size of the firm and their payouts. The findings confirmed that the firms which pay more dividends are the larger one. Many past studies have confirmed the findings of indicating the positive link of the size of the firms with the dividend payouts (Lloyd et al., 1985; Gilsenan, 1994; Holder et al., 1998 Mushtaq, 2016; Dąbrowska, 2020). In contrast, Jose (2001) found that the size of the firms does not significantly explain the dividend payouts.

\section{H3: Size has a positive impact on dividend payout.}

\section{Cash Flows and Dividend Payouts}

The agency cost theory assumes positive relations between cash flow and dividend pay ratio. A firm's cash flow represents its liquidity and it is essential to compare a firm's liquidity position in relation to its dividend payment. According to Amidu and Abor (2006), cash dividend distribution does not only depends on the profitability of firms but also depends on the free cash flow which is the amount of operating cash flow left over after the payment for capital expenditures. The findings of Echchabi and Azouzi (2016) 
and Dąbrowska (2020) indicated that net cash flow had a positive and significant effect on dividends in Tunisian companies. However, Deehani (2003) found cash flow to have a negative impact on dividend payments where firms facing high levels of cash flow uncertainty are likely to pay low dividends fearing cash shortfalls in the future.

\section{H4: Cash flows have a positive impact on dividend payout.}

\section{Financial Slack and Dividend Payouts}

Financial slack is funding to actualize investment opportunities, rather than rely on bank borrowing or the issuance of stock thus managers give internal reserve funds or financial slack preference in order to actualize investment opportunities. In general practice, the firm pays dividends to its shareholders after all the investments made. Fama and French (2001) assert that investment opportunities affect dividend payout decisions. They found that companies with better growth and investment opportunities have a lower dividend payment. Consequently, many of the previous studies (Jose, 2001; Mehar, 2003; AlDeehani, 2003; Amidu \& Abor, 2006; Alzomaia, 2013; Ritha \& Koestiyanto, 2013; Tahir \& Mushtaq, 2016) have found a significant negative relationship between the investment opportunities or slack and the dividend payouts confirming that the presence of higher slack reduces the dividends.

H5: Slack has negative impact on dividend payout.

\section{Methods}

\section{Research Design}

This study has employed descriptive and correlation research designs to determine the comparative status of dividend payout ratio and five determinants influencing dividend decision. Descriptive statistics and the one-sample t-test attempt to describe the comparative study. Moreover, the correlational research design has been employed in order to investigate the direction and magnitude of the association of dividend determinates with dividend payout ratio.

\section{Nature and Sources of Data}

The secondary data has been employed in order to analyze the form of the relationship between dividend policy and factors affecting it. The data for firm-specific variables including dividend payout ratio, net profits, market to book value ratio, total assets, cash flow, and slack have been collected from databases (annual reports) provided on websites of the banks. The study is based on the panel data of 19 selected banks 
commercial banks for the period of 5 years from 2013/14 to 2018/19. Similarly, the data available in NEPSE, SEBON, and NRB have also been used.

\section{Population and Sample}

The population of this study includes all commercial banks listed in Nepal Stock Exchange (NEPSE), the only secondary capital market in Nepal.

Table 1

Summary of Sample Banks and Number of Observations

\begin{tabular}{|c|c|c|c|}
\hline Bank Group & Bank Name & Symbol & $\begin{array}{l}\text { No of } \\
\text { Observations }\end{array}$ \\
\hline \multirow{7}{*}{$\begin{array}{l}\text { Joint } \\
\text { Banks }\end{array}$} & Nabil Bank Ltd. & NABIL & 5 \\
\hline & Himalayan Bank Ltd. & HBL & 5 \\
\hline & Standard Chartered Bank Nepal Ltd. & SCBNL & 5 \\
\hline & Nepal SBI Bank Ltd. & NSBI & 5 \\
\hline & Nepal Bangladesh Bank Ltd. & NBB & 5 \\
\hline & Everest Bank Ltd. & EBL & 5 \\
\hline & NMB Bank Ltd. & NMB & 5 \\
\hline \multirow[t]{12}{*}{ Private Banks } & Nepal Investment Bank Ltd. & NIBL & 5 \\
\hline & Sanima Bank Ltd. & SBL & 5 \\
\hline & NIC Asia Bank Ltd. & NICA & 5 \\
\hline & Global IME Bank Ltd. & GIBL & 5 \\
\hline & Machhapuchhre Bank Ltd. & MBL & 5 \\
\hline & Sunrise Bank Ltd. & SRBL & 5 \\
\hline & Laxmi Bank Ltd. & LBL & 5 \\
\hline & Siddhartha Bank Ltd. & SBL & 5 \\
\hline & Citizen Bank International Ltd. & CZBIL & 5 \\
\hline & Century Commercial Bank Ltd. & CCBL & 5 \\
\hline & Janata Bank Ltd. & JBNL & 5 \\
\hline & Mega Bank Nepal Ltd. & MEGA & 5 \\
\hline Total Obse & & & 95 \\
\hline
\end{tabular}

The sample represents data regarding study variables of 12 listed domestic private banks and 7 of the listed joint-venture banks. A total of 95 observations of total 19 banks and five years of data of each study variable regarding various dependent and independent variables have been collected and analyzed. The sample represents 35 observations from 
the joint ventures and 60 observations from domestic private banks. A probability stratified sampling technique has been employed to categorize sample banks in two strata namely domestic private banks. This method of selecting a sample based on an assessment of few criteria for samples that are designed for the purpose of the study, such as: first, the banks are still listed in the NEPSE during the study period is 2018/19 through 2013/14. Second, the bank has published required financial reports as annual financial statements for the study period, and final is the bank that consistently pays dividends during the study period.

\section{Methods of Analysis}

The study examines the relationship of corporate dividend payout, with some of the common dividend payout determinant variables, such as net profits, market to book value, size of the firms, cash flow, and investment opportunity. The descriptive cum Correlational research designs are employed to achieve the study purpose. The descriptive research design has described as the status of dividends and other determinant variables for five continuous fiscal years. The Correlational research design attempts to indicate the association of dividend on five of its determinants, the independent variables of the study. SPSS 13.0 was used to process and analyze the study variables.

\section{Study variable definition and model for analysis}

- Dividend Payout Ratio (DPR): Dividend is the portion of the net profit distributed to the shareholders on a proportionate basis. The DPR has been calculated as the dividend per share of the bank by earning per share of the firm.

- Net Profit: Net profit is the amount achieved after deducting operating and all other expenses including taxes and interest paid from gross profit. Profit after tax transferred to "Profit and Loss Appropriation Account"

- Cash Flow: It represents net cash flow after considering cash receipt and payments from operating activities, financing activities, and investing activities. The study uses net cash or free cash flows of the banks depicted in their cash flow statements

- Size of the Firm: The large firms are more likely to be mature and thus have easier access to capital markets and should be able to pay more dividends. Total assets have been used as the proxy for the size of the firms.

- Market to Book Value: The Market to Book value indicated by the market to book ratio is a financial valuation metric used to evaluate a company's current market value relative to its book value. Market Book Value has been calculated as dividing the market price per share by book value per share. 
- Slack: The slack (financial) is the unused capacity for debt and is equivalent to the unutilized cash that a company has on hand. This extra money is available to help a company survive difficult times, such as decreases in sales, revenues, or profits. The slack has been calculated as the accumulated retained earnings divided by the total assets of the firm.

To examine the impact of net profit, cash flow, size (total assets), market to book value, and slack on dividend payout ratio the casual comparative research design has been used. The regression model expressing the linear relation of these independent variables on dividend payout ratio (DPR) can be modeled as follows:

$\mathrm{DPR}_{\mathrm{i}}=b_{0}+b_{1} \times$ Net profit $_{i}+b_{2} \times$ Cash flow $_{i}+b_{3} \times$ Size $_{i}+b_{4} \times$ Market to book value $_{i}+b_{5} \times$ Slack $_{i}+\mu_{i t}$

Where $b_{0}$ denotes the intercept of the regression equation, and $b_{1}, b_{2}, b_{3}, b_{4}$, and $b_{5}$ are the regression coefficients of net profit, cash flow, size (total assets), market to book value, and slack.

\section{Results and Discussions}

\section{Descriptive statistics}

Table 2 depicts the descriptive statistics of five determinants of dividend payout used for the study. The data indicate the result of 95 observations for five years of data of the study variables.

Table 2

Descriptive statistics of dividend payout ratios and its determinants

\begin{tabular}{llllll}
\hline Study Variables & Minimum & Maximum & Mean & Range & $\begin{array}{l}\text { Std. } \\
\text { Dev. }\end{array}$ \\
\hline Dividend Payout Ratio (in \%) & 9.09 & 50.71 & 24.43 & 41.62 & 11.92 \\
Net Profit (NPR in billion) & 0.45 & 2.98 & 1.28 & 2.53 & 0.68 \\
Cash Flows (NPR in billion) & 0.16 & 2.54 & 1.19 & 2.38 & 0.73 \\
Size; Total assets (NPR in billion) & 40.58 & 128.6 & 73.18 & 88.02 & 27.51 \\
Market to Book Ratio (in ratio) & 2.68 & 8.82 & 4.51 & 6.14 & 1.73 \\
Slack (in \%) & 0.68 & 5.26 & 2.64 & 4.58 & 1.41 \\
\hline
\end{tabular}

Table 2 provides the descriptive statistics for all the regression variables. This shows the average indicators of variables computed from the financial statements. The average standard dividend payout ratio is 24.43 percent and the average profitability is 1.27 billion for the study period. This means, on average, banks pay about 24 percent of their profits as dividends. Cash flow on average reported to Rs. 1.19 billion and market to book value ratio and slack ratios came to 1.51 and 2.64 percentage respectively. 
Comparatively, the standard deviation for the observation is higher of dividend payout ratio indicating more divergent dividend rates applied by the sample banks during the study period.

\section{Regression analysis}

The regression analysis has been conducted to examine the impact of all five independent variables on the dividend payout ratio. Tables 2 and 3 provide test statistics regarding the linear relationships of the study variables.

Table 3

Multicollinearity and Regression Model Statistics

\begin{tabular}{lll}
\hline \multirow{2}{*}{ Variables } & \multicolumn{2}{l}{ Collinearity statistics } \\
\cline { 2 - 3 } & Tolerance & VIF \\
\hline Net profit & 0.075 & 13.314 \\
Cash flow & 0.63 & 1.587 \\
Size & 0.091 & 11.048 \\
MBR & 0.467 & 2.143 \\
Slack & 0.35 & 2.858 \\
R & 0.953 & \\
R Square & 0.909 & \\
Adjusted R square & 0.874 & \\
Durbin Watson & 2.305 & \\
F-statistic & 25.87 & \\
Significance & 0 & \\
\hline
\end{tabular}

The Durbin Watson (DW) statistic 2.305 has indicated that there is no autocorrelation detected in the sample of the study variables. In the case of multicollinearity, since all tolerance statistics and variance inflation factor (VIF) of the variables (excluding net profit) are within the range can also, therefore, there is no issue of multicollinearity. Similarly adjusted $\mathrm{R}$ in the regression model is 0.874 . It means that the ability of five used independent variables in explaining the dependent variable (DPR) of the sample banks for the period. The statistic of F-value of is 25.87 ( $p$-value=.000) shows that independent variables simultaneously affect the dependent variable that is Dividend Payout Ratio on the banks.

Table 4 depicts the regression results of this study where the dependent variable is dividend payout, is regressed using the SPSS software against five explanatory variables 
including; profitability, cash flow, firm size, market to book value, and investment opportunity.

Table 4

Impact of the independent variables on dividend payout ratio

\begin{tabular}{lllll}
\hline Variables & Beta & t-value & p-value & Remarks \\
\hline Net profit & -0.232 & -0.759 & 0.461 & Rejected \\
Cash flow & -0.144 & -1.365 & 0.195 & Rejected \\
Size (Total assets) & 0.438 & 1.571 & 0.14 & Rejected \\
Market to book value & 0.379 & 3.087 & 0.009 & Accepted \\
Slack & 0.539 & 3.803 & 0.002 & Rejected \\
\hline
\end{tabular}

The regression results show that the impact of net profit (Coefficient: -.232, t-value: .759 and p-value: 461 ) found to be insignificant and negative hence the alternative hypothesis has been rejected. Similarly, the cash flows (Coefficient: -0.144 , t-value: 1.365 and p-value: .195) of the banks also have an insignificant and negative impact on the dividend payout ratio and thus the alternative hypothesis was rejected. These results may have produced due to the liquidity problem faced by the retail banking sector a few years ago which affected both the cash flows and profitability indexes.

Similarly, the size of the banks has a positive but insignificant effect on the dividend payout ratio (Coefficient: .438, t-value: 1.571 and p-value: .140) so the alternative hypothesis has been rejected. Consequently, market to book value and thus supported for acceptance of the alternative hypothesis. However, the slack of the banks seems to have a positive and significant impact on the dividend payout ratio. However, theoretically investment opportunity has a negative impact on dividend payout ratio thus the alternative hypothesis has been rejected. In aggregate, the dividend payout ratio for the observation period was positively and significantly influenced by two of the independent variables-Slack and market to book value. The effect of bank size on dividend payout was the positive but not significant impact and rest two variables; profitability and cash flow produced a negative influence on the dividend payout of the banks.

\section{Conclusion}

The regression results of this study where the dependent variable is dividend payout is regressed using the SPSS software against five explanatory variables including; profitability, cash flow, firm size, market to book value, and investment opportunity. The regression results show that the influence of net profit of the banks on dividend payout 
ratio found negative thus inconsistent with findings of Eriotis (2005); Amidu and Abor (2006): Ahmed and Javid (2009); Malik et al. (2013); Demirgüneş (2015); Tahir \& Mushtaq (2016); and Justyna et al. (2019). Similarly, the negative relation between cash flow with dividend payout ratio as resulted in this paper is inconsistent with the findings of Amidu and Abor (2006); Echchabi and Azouzi (2016), and Justyna et al. (2020). The positive influence of size on the dividend is consistent with the results of Eriotis (2005); Gilsenan, 1994; Holder et al., 1998 Mushtaq, 2016; Dąbrowska, 2020). In contrast, Jose (2001) found that the size of the firms does not significantly explain the dividend payouts. Consequently, the positive and significant effect of the market to book value and financial slack on dividend payout ratio observed in this study supports the findings of Tahir and Mushtaq (2016) and Echchabi and Azouzi (2016).

\section{Implications}

This paper examined the effect of dividend determinants on dividend payout ratio and revealed mixed results. The findings of this study are useful for managerial implication and reference for future studies. Basically, investors are more concerned for analyzing more effective determinant that signals future possible dividend payout. The result from five years observation has indicated that only profit and cash flows are not major factors that determine dividend ratio but available financial slack and market to book value ratio are strong determinants of dividend. The study is done using a small number of observations of the retail banking sector only thus future studies should consider manufacturing and other non-manufacturing sectors. Similarly, many other factors affecting dividend decisions have been excluded which should be studied by future studies.

\section{References}

Ahmed, H., \& Javid, A. (2009). Dynamics and determinants of dividend policy in Pakistan: An evidence from Karachi stock exchange non-financial listed firms. International Research Journal of Finance and Economics , 4(25), 149-171.

Al-Deehani, T. M. (2003). Determinants of Dividend Policy: The Case of Kuwait. Journal of Economic and Administrative Sciences, 19(2), 5976. https://doi.org/10.1108/10264116200300006

Al-Kuwari, D. (2009). Determinants of the dividend policy in emerging stock exchanges: The case of GCC countries. Global Economy \& Finance Journal , 2 (2), 38-63. Allen, F., \& Michaely, R. (2003). “Payout policy” North-Holland handbook of economics edited by George Constantinides. Milton Harris, and Rene Stulz; North-Holland. 
Al-Malkawi, H. A. (2007). Determinants of corporate dividend policy in Jordan: An application of Tobit Model. Journal of Economic and Administrative Sciences, 23(2), 44-70.

Al-Malkawi, H. N. (2007). Determinants of corporate dividend policy in Jordan: an application of the Tobit model. Journal of Economic \& Administrative Sciences, 23(2), 44-70.

Alzomaia, T., \& Al-Kadhiri, A. (2013). Determination of Dividend Policy: The Evidence from Saudi Arabia. Journal of Business and Social Science, 4(1): 5-18.

Amidu, M., \& Abor, J. (2006). Determinants of dividend payout ratios in Ghana. The Journal of Risk Finance, 7(2), 136-145. doi:10.1108/15265940610648580

Baker, H. K., Veit, E. T., \& Powell, G. E. (2001). Factors influencing dividend policy decisions of NASDAQ firms. The Financial Review, Eastern Finance Association , 5(1), 1-22.

Baker, H., \& Powell, G. (2000). Determinants of corporate dividend policy: A survey of NYSE firms. Financial Practice \& Education , 10(1), 29-40.

Brealey, R. A., Myers, S. C., \& Allen, F. (2008). Principles of corporate finance (9th ed.). New York: McGraw-Hill Education.

Dąbrowska, J. F., Sawicka, M. M., \& Ulrichs, M. (2020). Determinants of dividend payout decisions -the case of publicly quoted food industry enterprises operating in emerging markets, Economic Research-Ekonomska Istraživanja, 33(1), 1108-1129, DOI: 10.1080/1331677X.2019.1631201

Demirgüneş, K. (2015). Determinants of target dividend payout ratio: a panel autoregressive distributed lag analysis. International Journal of Economics and Financial Issues, 5(2), 418-426.

Echchabi, A., \& Azouzi, D. (2016). Determinants of dividend payout ratios in Tunisia: insights in light of the jasmine revolution. Journal of Accounting, Finance and Auditing Studies, 2(1), 1-13

Eriotis, N. (2005). The effect of distributed earnings and size of the firm to its dividend policy: Some Greek data. International Business and Economic Journal , 4(167), 45-78.

Eriotis, N. (2005). The effect of distributed earnings and size of the firm to its dividend policy: some Greek data. International Business \& Economics Research Journal, IBER) 4(1), 67-74, DOI: 10.19030/iber.v4i1.3568

Fama, E. F., \& Babiak, H. (1968). Dividend policy: An empirical analysis. Journal of the American Statistical Association, 1132-1161.

Fama, E. F., \& French, K. R. (2001). Disappearing dividends: Changing firm characteristics or lower propensity to pay? Journal of Financial Economics, $60(1), 3-43$. 
Foong, S. S., Zakaria, N. B., \& Tan, H. B. (2007). Firm performance and dividend related factors: the case of Malaysia. Labuan Bulletin of International Business and Finance , 5(3), 97-111.

Foong, S., Zakira, N., \& Tan, H. S. (2007). Firm Performance and Dividend-Related Factors: The Case of Malaysia. Labuan Bulletin of International Business \& Finance, 5, 2007, 95-109.

Gill, A., Biger, N., \& Tibrewala, R. (2010). Determinants of dividend payouts ratios: Evidence from United States. The Open Business Journal (3), 8-14.

Gilsenan, J. D. (1994). Determinants of corporate capital structure and dividend policy: Theory and evidence. The University of Queensland, Department of Commerce,. Queensland: Unpublished Honours Dissertation.

Holder, E. M., Langrehr, F. W., \& Hexter, J. L. (1998). Dividend policy determinants: An investigation of the influences of stockholder theory. Financial Management, 27(3), 73-82.

Holder, M. E., Langrehr, F. W., \& Hexter, J. L. (1998). Dividend policy determinants: an investigation of the influences of stakeholder theory. Financial Management, 27(3), 73-82.

Javid, A. Y., \& Ahmed, H. (2009). Determinants of dividend policy in Pakistan. International Research Journal of Finance and Economics. 29, 110- 125.

Jose, M. L. (2001). Capital market valuation of dividend policy. Journal of Business Finance and Account , 16(5), 59-65.

Justyna, F. D., Magdalena, M. S., \& Magdalena, U. (2020)..Determinants of dividend payout decisions - the case of publicly quoted food industry enterprises operating in emerging markets. Economic Research, 33(1), 1108-1129.

Reddin, L. S. (1997). Firm Size and Dividend Payouts. Journal of Financial Intermediation, 6(3), 224-248.

Lolyd, J. S., \& William, P. (1985). Agency costs and dividend payout ratios. Quaterly Journal of Business and Economics , 24(3), 19-29.

Malik, F., Gul , S. , Khan, M. T., Rehman, S., \& Khan, M. (2013). Factors influencing corporate dividend payout decisions of financial and non-financial firms. Research Journal of Finance and Accounting, 4(1), 35-46.

Mehar, A., (2003). Corporate governance and dividend policy. MPRA Paper 619, University Library of Munich, Germany.

Miller, M. H., \& Rock, K. (1985). Dividend policy under asymmetric information. The Journal of finance, 40(4), 1031-1051. http://dx.doi.org/10.1111/j.15406261.1985.tb02362.x 
Miller, M., \& Modigliani, F. (1961). Dividend policy, growth, and the valuation of shares. Journal of Business, 34(4), 411-33. http://dx.doi.org/10.1086/294442

Tahir, M., \& Mushtaq, M. (2016). Determinants of dividend payout: evidence from listed oil and gas companies of Pakistan. Journal of Asian Finance, Economics and Business. 3(4), 25-37.

Myers, S. C. (1984). The capital structure puzzle. The journal of finance, 39(3), 574-592.

Omran M., \& Pointon J. (2004). Dividend policy, trading characteristics, and share prices: empirical evidence from Egyptian firms. International Journal of Theory and Applied Finance, 7, 121-30.

Pruitt, S. W., \& Gitman, L. J. (1991. The interactions between the investment, financing, and dividend decisions of major U.S. enterprises. Financial Review. 26(3), 409430.

Pruitt, S. W., \& Gitman, L. W. (1991). The interactions between the investment, financing and dividend decisions of major US firms. Financial Review , 26 (33), 409-430.

Refra, E., \& Widiastuti, dan-M. C. (2014). Pengaruh profitability, firm size, tax, investment opportunities, life cycle stage terhadap dividend policy pada industri manufakturdi Indonesia. Journal Manajemen Fakultas Ekonomi Universitas Trisakti,1(2),(2014): 84-105.

Ritha, H., \& Koestiyanto, E. (2013). Faktor-faktor yang mempengaruhi dividend payout ratio. e-Journal Manajemen dan Bisnis, 1(1): 1-15.

Shubiri, A. N. (2011). Determinants of changes dividend behavior policy: evidence from the Amman stock exchange. Far East Journal of Psychology and Business, Far East Research Centre, 4(1), 1-15.

Tahir, M., \& Mushtaq, M (2016). Determinants of dividend payout: evidence from listed oil and gas companies of Pakistan. Journal of Asian Finance, Economics and Business, 3(4), 25-37. 